\title{
PDIG/GOIÂNIA (1968): A INSERÇÃO DA QUESTÃO HABITACIONAL NA METODOLOGIA URBANISTICA DE JORGE WILHEIM
}

Pdig/Goiânia (1968): The Insert Of The Housing Issue In Urbanistic Methodology Of Jorge Wilheim

\author{
Wilton Araujo Medeiros \\ Universidade Estadual de Goiás \\ wilton_68@hotmail.com
}

\section{Resumo}

Há uma teoria da cidade subdesenvolvida que direciona o trabalho de Jorge Wilheim como urbanista para o SERFHAU, para a qual propõemétodos urbanísticos. $O$ desenvolvimento desses métodos é apresentado na obra Urbanismo no subdesenvolvimento, juntamente com a exposição do modo como elaborou diversos Planos Integrados para cidades brasileiras até 1968. Entre 1968 e 1969, ao elaborar o Plano de Desenvolvimento Integrado de Goiânia (PDIG), Wilheim insere a politica habitacionalcomo aspecto da metodologia urbanistica para cidades subdesenvolvidas. Com isso, configura no PDIG uma hipótese morfólogica de desenvolvimento urbano de Goiânia no sentido Leste-Oeste, intencionando inibir a acelerada expansão no sentido Norte-Sul. Teoricamente, esse seria para Wilhiem um urbanismo crítico em que, o "fisicismo" urbano seria contraposto pela metodologia do "caráter específico" da cidade, metodologia, por assim dizer, de "estrutura germinativa".

\section{Palavras-chave}

Habitação; urbanismo; Plano Integrado.

\section{Abstract}

There is a theory of underdeveloped city that directs the work of Jorge Wilheim as town planner for the SERFHAU, for which proposes urban methods. The development of these methods is presented in Urbanism in underdevelopment, along with the exhibition the way prepared several integrated plans for Brazilian cities until 1968.Between 1968 and 1969, when drawing up the plan for comprehensive development of Goiânia (PDIG), Wilheim inserts housing policy as an aspect of town planning methodology for underdeveloped cities. With this configuration in PDIG a morphological hypothesis of urban development of Goiania in East-West 
direction,intending inhibit accelerated expansion in North-South direction.Theoretically, this would be for Wilheim a critical urbanism that the "physicalism"urban would be opposed by the methodology of "specific character" of the city, methodology, so to speak, of "germination" structure.

\section{Keywords}

Housing; urbanism; Integrated Plan.

\section{Introdução: problemas da habitação e formação dos tecidos urbanos de padrão periférico}

A inserção da questão habitacional na metodologia urbanística de Jorge Wilheim deu-se precisamente quando elaborou o Plano de Desenvolvimento Integrado de Goiânia (PDIG), entre 1968 e 1969. Anteriormente à feitura do PDIG, Jorge Wilheim já tinha acumulado experiência de mais de dez anos atuando com urbanismo, tendo inclusive participado do concurso para o Plano Piloto de Brasília. No decorrer dessa atuação, a maior característica do seu trabalho talvez tenha sido a buscapela formulação de metodologias do projeto urbanístico. E é provavelmente devido a esse perfil de atuação profissional que em 1969 o SERFHAU irá contratá-lo para a proposição de subsídios à reformulação metodológica do planejamento urbano no Brasil $^{1}$.

Como mostra Feldman (2005), o longo período de institucionalização do planejamento urbano no Brasil, a particularidade do momento de Criação do SERFHAU está na introdução de empresas de engenharia consultiva para a elaboração de Planos Diretores Integrados. Outra particularidade, inerente a essa, é que com isso, se estabelece a chancela de um órgão federal para contratação, pelos governos municipais, de empresas de consultoria para elaboração de planos. É nesse contexto que atuará o arquiteto e urbanista Jorge Wilheim, através da firma SERETE Engenharia.

ConformeAb'Saber(1969: 21), durante os anos de 1960 o governo federal dava condições de financiamento para que os municípios elaborassem Planos Diretores Integrados, pressionando-os de certo modo, a buscarem a participação de empresas de consultorias como a SERETE que elaborou o PDIG. Então, ao elaborar o

\footnotetext{
1"O autor fora contratado por essa entidade, para propor subsídios à reformulação metodológica do planejamento urbano. Nesta tarefa colaboraram também: Lenina Pomerantz (economista), O. Ianni (sociólogo), MM. Mello (técnico em administração) e, pelo SERFHAU: Nina Rennó, E. Novaes e M. Pinheiro". (WILHEIM, 1969: 377). 
PDIG, Wilheim já havia participado dos planejamentos integrados de Curitiba (1965), Joinville (1965), Osasco (1966), Plano do vale urbano do Tietê (1966) e Natal (1967).

Além da larga experiência que o trabalho na SERETE foi the proporcionando, devido a esse foco na metodologia urbanística, Wilheim também se colocava como um teórico do urbanismo, como seguiu fazendo muitas décadas depois, embora não admitisse $^{2}$. De fato, somente uma leitura dos dois volumes do PDIG - ou de qualquer outro Plano anterior ao de Goiânia -, não seria suficiente para perceber que por trás de sua atuação profissional há alguém preocupado em fundamentar-se teoricamente, e, sobretudo, contribuir para a epistemologia do urbanismo. Para compreender isso, se faz necessária a leitura dos livros que publicou ${ }^{3}$.

Esse interesse pelo conhecimento teórico do urbanismo vai ficar mais evidente no conteúdo de suas diversas publicações. No caso em tela sobre o PDIG, no livroUrbanismo no subdesenvo/vimento publicado pela Editora Saga em 1969, um ano após a entrega do PDIG à Prefeitura de Goiânia. Este livro marca a inserção da "questão habitacional"como teoria e metodologia urbanística na trajetória profissional de Jorge Wilheim, assunto tratadono presente texto.

Porém, para entendermos que a inserção da questão habitacional como metodologia urbanística por Wilheim deve-se muito mais ao contexto do planejamento urbano no Brasil do que propriamente a uma questão de autoria, é preciso um sucinto olhar sobre a influencia do pensamento arquitetônico no que se refere a inter-relação entre o problema da moradia e o do crescimento vertiginoso das cidades.

Como mostra Bonduki (2004), a formação de um padrão periférico no crescimento das cidades brasileiras entre 1937 e 1964, teve a ver com a incapacidade do Estado em equacionar o problema da moradia. Devido a essa incapacidade, o problema da moradia acaba expandindo e consolidando as soluções informais através do auto-empreendimento. Segundo Campos e Mendonça (2013) e Ribeiro e Azevedo (1996), esse mesmo padrão periférico, inter-relacionado ao problema da moradia, permanece no período de funcionamento do BNH (1964-86), período em que a construção civil contou com uma fonte de financiamento estável (recursos do FGTS e SBPE) para a produção de moradias novas, mas contribuiu muito pouco para

\footnotetext{
2"Contribuições de um profissional liberal e não de um acadêmico nem de um intelectual stricto sensu. Nada sou no stricto sensu, vivo no lato sensu, buscando abarcar a interdisciplinaridade humanista. (WILHEIM, 2011, p. 14).

${ }^{3}$ São Paulo Metrópole 65: corpo e alma do Brasil. São Paulo: Editora DIFEL, 1965; Cidades: o substantivo e o adjetivo. São Paulo: Editora Perspectiva, 1976; Projeto São Paulo: propostas para a melhoria da vida urbana. São Paulo: Editora Paz e Terra, 1982; Espaços e Palavras. São Paulo, Projeto (Cadernos brasileiros de arquitetura, v.15), 1985; Intervenções na paisagem urbanade São Paulo. São Paulo, Instituto Florestan Fernandes/ Jorge Wilheim Consultores Associados, 2000.
} 
enfrentar o problema que o órgão se propunha a resolver, ou seja, viabilizar o acesso à casa própria pela população de mais baixa renda.

Trata-se, no dizer de Souza (2008: 36;39), de uma questão cuja "essência estrutural" está relacionada à urbanização intensiva e ao desenvolvimento industrial, resultando porém em configurações espaciais próprias. Essas configurações espaciais próprias exigem uma compreensão retrospectiva em relação à questão da posse da terra como mercadoria, a qual, no Brasil, tem suas bases fincadas na Lei de Terras de 1850 (ROLNIK, 1997).

No decorrer da década de 1960, as cidades cresciam de forma avassaladora, e o Brasil se deslocava para o Planalto Central. Moraes (2003) observa que, tanto em Goiânia quanto em Brasília mesmo o Estado sendo o maior proprietário fundiário, fez com que perpetuasse o padrão periférico, já que favorecendo a especulação imobiliária, perpetuou também a incapacidade do Estado em equacionar o problema da moradia: "quanto mais pobre o trabalhador, mais distante do centro urbano localizava-se o seu hábitat" (pág. 184). Bonduki (2004) observa que, de um modo geral, mesmo tendo iniciadacom o sistema SFH/BNHsignificativa produção de habitação social perdeu-se a oportunidade de reestruturar de modo efetivo a intervenção habitacional.

Por outro lado, nesse contexto, o pensamento arquitetônico e urbanístico, dava muita relevância ao tema da habitação social. Isso era decorrente das utopias de "função social" das vanguardas modernas sobre "habitação mínima" (KOPP, 1990:54), e também devido ao fato de nos programas arquitetônicos passarem a constar uma gama variada de equipamentos coletivos - onde funcionaria uma espécie de efeito demonstração da sociedade socialista (TAFURI, 1986). Essa preocupação profissional com a questão social da moradia, ressalta Maricato (2001),contribuiu na formulação de propostas do Seminário de Reforma Urbana promovido pelo IAB em 1963, as quais na sua maioria foram apropriadas e adotadas pelo sistema $\mathrm{SFH} / \mathrm{BNH}$, ao qual pertencia o SERFHAU.

Embora após a implantação do sistema SFH/BNH o significado socializante tenha sido drasticamente reduzido, e, como dizem Bastos e Zein (2010: 167; 303) a vontade de relacionar a arquitetura habitacional com temas de ordem socioeconômica, politica e cultural acabar deixando a arquitetura propriamente dita de lado - "para o pensamento arquitetônico e urbanístico moderno, o projeto da habitação social é um objetivo máximo; mas, na prática, acaba sendo um tema secundário, do qual muito se espera e pouco, efetivamente, resulta" - o tema da habitação passará a ser interligado ao do planejamento urbano, associados à 
industrialização e à reorganização do tecido urbano. É precisamente ao âmbito morfológico da reorganização do tecido urbano que Wilheim passará a incorporar a questão habitacional à metodologia urbanística.

Portanto, a incorporação da questão habitacional na metodologia urbanística de Wilheim, tem a ver com esse contexto do pensamento arquitetônico e urbanístico, em que a associação entre as soluções propostas para os problemas da habitação e a formação dos tecidos urbanos é uma das principais maneiras pelas quais o trabalho dos arquitetos passará a ser requerido no âmbito da atuação do sistema $\mathrm{SFH} / \mathrm{BNH}$, mais especificamente no SERFHAU e sua politica de planejamento integrado. Como vai dizer Reis Filho (1965: 24), "somente nessas oportunidades adquirem toda a sua significação, as soluções plásticas e construtivas das obras de alguns arquitetos". É essa direção do pensamento arquitetônico que caracteriza a ênfase morfológica do planos urbanísticos no âmbito do planejamento integrado, e, mais especificamente a inserção da questão habitacional que vai nortear a feitura do PDIG.

\section{Buscando fundamentar a inserção da questão habitacional como diretriz de desenvolvimento urbano: o caso do PDIG}

Buscando fundamentar a inserção da questão habitacional como diretriz de desenvolvimento urbano, Wilheim dialoga com diversos economistas e urbanistas, a fim de encontrar a peculiaridade da cidade latino-americana "subdesenvolvida", na última página do capítulo dedicado ao PDIG, Wilheim faz o seguinte registro:

Ao terminar este livro, o Plano de Goiânia foi entregue; adquiriram nele especial relevo: a criação da Superintendência de Planejamento, o desenvolvimento para Oeste, o programa prioritário de abertura e pavimentação das vias Leste-Oeste, o reforço de equipamento de certos polos, o adensamento do Jardim América e o uso estratégico dos novos conjuntos habitacionais. (WILHEIM, 1969).

Com a criação da Superintendência de Planejamento em Goiânia, é sem duvida pertinente observar que houve superação do embate político entre o governo estadual e o municipal pela gestão urbana, que a décadas era travado, e muito provavelmente é um dos fatores que particularizam a tensa relação entre urbanismo e urbanização em Goiânia. Como disse Wilheim: "ressalte-se como específico de Goiânia, o problema da falta de entrosamento entre a Prefeitura e o Estado, o que tem causado sérias dificuldades ao planejamento das obras de água, esgoto, galerias pluviais e asfaltamento" (1969, p. 273). 
Como se verá a seguir, esse forte aspecto político de Goiânia contribuiu para que naquele momento o viés politico fosse incorporado aos fatores "germinativos" de sua metodologia, que pretendia ser critica ao urbanismo "fisicista". Buscando fundamentar a inserção da questão habitacional como diretriz de desenvolvimento urbano de Goiânia, Wilheim vai inicialmente mostrar que essa superação do "fisicismo" em prol de um urbanismo crítico significava integrar aspectos explicativos das estruturas urbanas e interpretativos dos sistemas de vida. $E$ que eram precisamente essas estruturas urbanas dispersivas, sem qualquer intervenção urbanística que pudesse Ihes restituir um sentido de "todo", as responsáveis pela cidade dispersiva. No caso, por meio das politicas habitacionais esse sentido do todo poderia ser traçado através de direcionamentos morfológicos.

Com isso, Wilheim apresenta três hipóteses lineares de desenvolvimento, sendo que no caso de Goiânia na questão do "caráter" da cidade ganha relevo a politica habitacional, incorporada na hipótese central de desenvolvimento linear da cidade no sentido Leste-Oeste. Por fim, Wilheim mostra que, embora a questão da "casa própria" estivesse diretamente relacionada às politicas habitacionais em Goiânia, para a "cidade subdesenvolvida" brasileira essa era uma questão bastante generalizável.

Conforme dito acima, só foi possível esse esforço de tentar compreender um pouco de sua metodologia urbanística dita "crítica", e a incorporação da questão habitacional no escopo de suas metodologias urbanísticas, porque a leitura foi feita a partir de seu livro Urbanismo no subdesenvolvimento, e, nele, o quinto capítulo da 3 a parte Goiânia: habitação como força agente (págs. 247-275), e não diretamente dos volumes do PDIG disponíveis atualmente disponíveis na biblioteca da Secretaria Municipal de Planejamento (SEPLAM). Neste livro, como podemos ver a seguir, os esquemas morfológicos de desenvolvimento deveriam ter como principio metodológico a integração dos aspectos explicativos e interpretativos da cidade em estudo.

\section{Integração de aspectos explicativos e interpretativos para esquemas morfológicos de desenvolvimento}

Durante suas visitas técnicas para a elaboração do Plano de Desenvolvimento Integrado de Goiânia, em 1968 e 1969, tanto Jorge Wilheim quanto sua equipe de trabalho observaram a pobreza de pavimentação da cidade. Para Wilheim, esse déficit de pavimentação era muito sentido pela população, seja porque a estiagem prolongada tornava ainda mais perniciosa a poeira, carreando de certo modo um frustrante sinônimo de civilização almejada pela população migrante, seja porque as 
características pouco urbanas das vias não pavimentadas limitava em muito o número de estruturas dominantes - com essa dupla observação sobre o déficit de pavimentação, Wilheim assinala, para Goiânia, dois aspectos marcantes na metodologia do trabalho urbanístico que executou para o SERFHAU em dezenas de cidades brasileiras: o aspecto explicativo e o aspecto interpretativo.

Wilheim acreditava na conjunção desses aspectos metodológicos como maneira de rever a urbanística tradicional, propondo crítica aos métodos "fisificantes" ou de nenhum "conteúdo humano". Wilheim acreditava no urbanismo como "técnica de transformação da realidade", com a qual passaria a assumir caráter de "uma estratégia e não a de uma mera ordenação dos espaços ou de recursos". Esta nova metodologia estaria dentro de um novo quadro de referências (qualitativo) no qual o urbanista contribuiria para a formulação das tendências existentes na cidade (WILHEIM, 1969, p. 89), pelas quais seus moradores despertariam para uma praxis social capaz de alterar a vida urbana, transformando espaços de consumo em espaços a serem usufruídos. (idem: 90).

Por meio dos aspectos explicativos e interpretativos, Wilheim explicita quais eram os aspectos estáticos (estruturas) e os aspectos dinâmicos (sistemas de vida) de uma cidade. Como veremos mais detalhadamente a seguir com respeito ao Plano de Desenvolvimento Integrado de Goiânia (PDIG), essa metodologia proposta por Wilheim apresenta maneiras distintas de analise, porém aparecem juntas na proposta morfológica como técnica de transformação da realidade. E é essa junção dos dois modos de analise que revelará o "caráter" do plano, expresso morfologicamente.

Com isso, Wilheim advogava que os arquitetos não deveriam ter receios em assumir o papel de orientador dos planos de desenvolvimento, porque eram precisamente as propostas morfológicas as estratégias que iniciariam os processos de transformação urbana: "percebe-se assim que cada plano se caracterizou por alguma ideia dominante que Ihe conferiu o seu caráter específico" (WILHEIM, 1969, p. 124).

Invariavelmente, o caráter específico ou a ideia dominante estaria ligado morfologicamente ao sistema viário, porque é o

elemento gerador e vetor de indução da ocupação do solo urbano: (...) retenhamos a fortíssima atração exercida pela via que abrimos ou pavimentamos. A ocupação se dará a seu longo, de forma cada vez mais densa. Sua função de estrada (transito, passagem, velocidade e predominância do veiculo) será gradativamente substituída por outra função (estacionamento, acesso a prédios e lojas, tráfego lento e predominância de pedestres). (...) Quando as funções chegarem a conflitar abrir-se-á a segunda 
via (anteriormente apenas legislada e projetada, mas não aberta), destinada apenas ao tráfego de passagem (1 a função). (WILHEIM, 107).
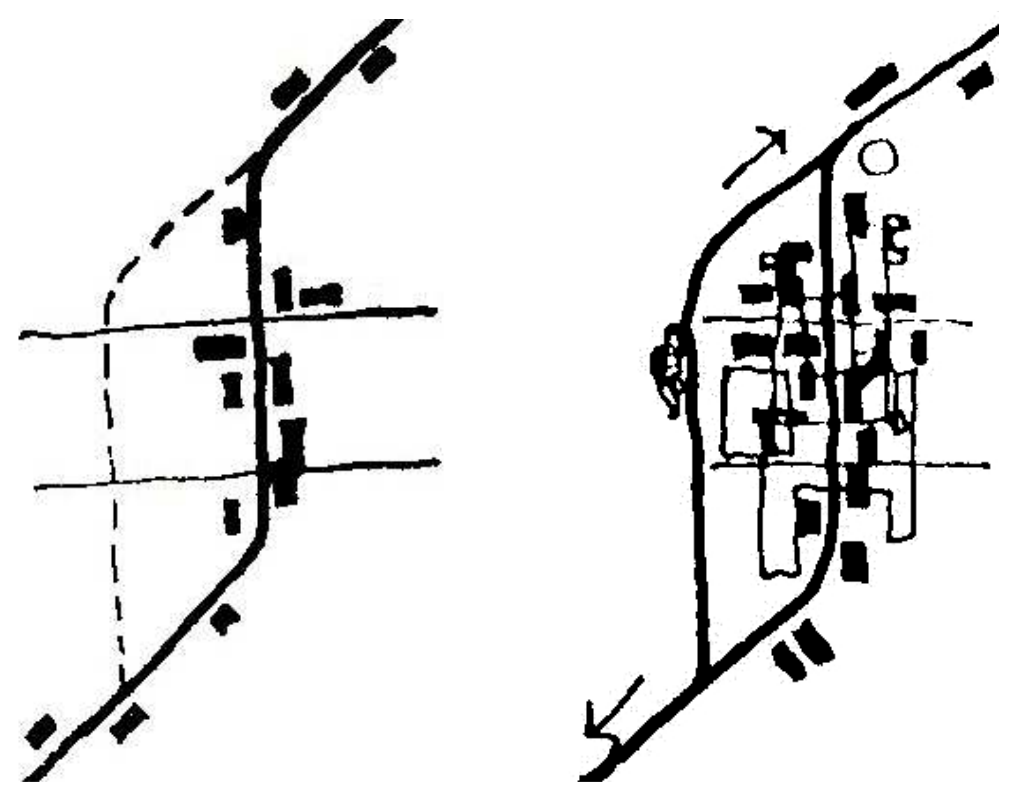

Figuras 1 e 2 - esquema do "binômio viário", proposto para sistematizar o elemento gerador e vetor de indução da ocupação do solo urbano.

Fonte: Wilheim, 1969: 107.

A análise dessa dinamicidade propiciada pelas vias suscitou um esquema morfológico para Goiânia (ver Figura 3, 4 e 5), assim como suscitou para as demais cidades objetos de planos Integrados feitos por Wilheim e sua equipe. Cuja força indutora, configuraria o "caráter germinativo" do desenvolvimento urbano, juntamente com o "caráter específico" da cidade. O "caráter específico" definido por Wilheim e sua equipe para Goiânia coincide com o que naquele período era o principal mote das políticas urbanas promovidas pelo Governo Federal - a questão da casa própria $^{4}$-, e aparece também no escopo de sua teoria das cidades como fundamental para explicar a periferização dos migrantes rurais aos se fixarem no espaço urbano. Desse modo, o "caráter específico" é obtido compondo-se o discurso da "casa e terra como forças agentes", a partir da interpretação do modo de vida em Goiânia nos anos de 1960 (ver Figura 6).

Conforme proposto pelo PDIG, os três esquemas morfológicos germinativos deveriam lançar três hipóteses mutuamente excludentes:

\footnotetext{
${ }^{4}$ Segundo AZEVEDO (1976, p. 76), o SERFHAU nasceu com a finalidade de ser um órgão estritamente ligado a habitação, não só como herdeiro da Fundação da Casa Popular, como também pela ênfase que foi dada à habitação no conjunto das suas atribuições na Lei4380/64 o planejamento urbano ocupava uma posição claramente secundária, e a habitação era o tema central, fazendo com que o plano diretor se apoiasse na habitação, e não o contrário.
} 


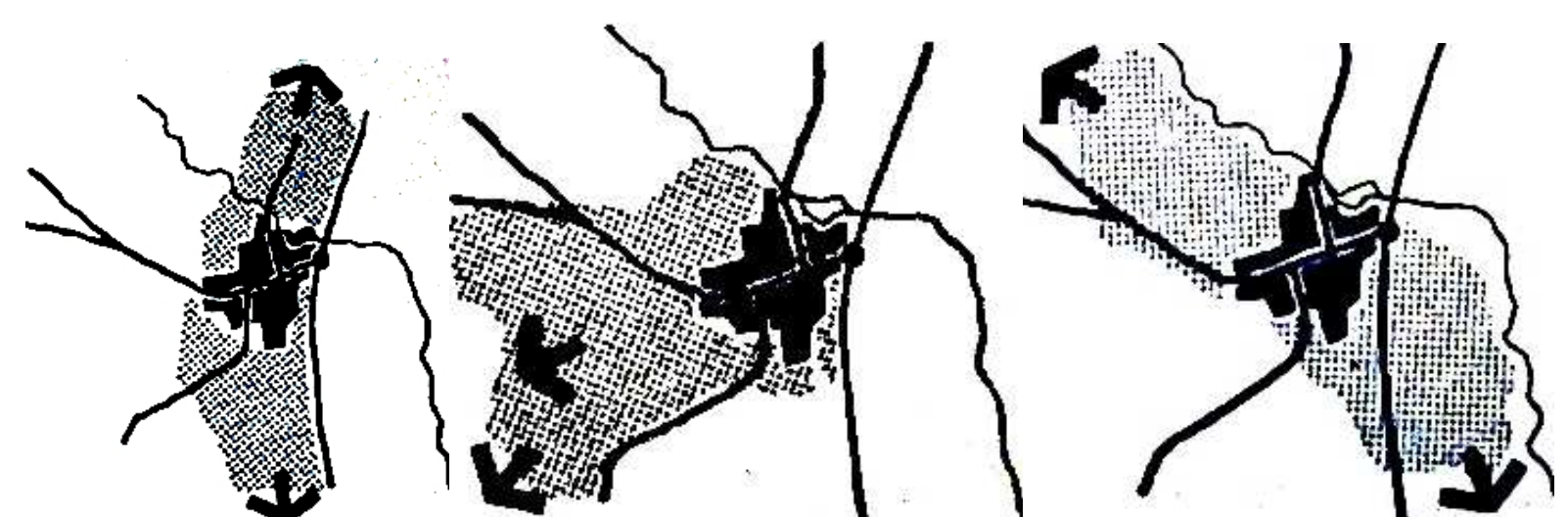

Figuras 3, 4 e 5 - alternativas de vetores lineares de expansão para Goiânia, mutuamente excludentes, proposto para que fossem implantados a partir dos anos de 1970.

Fonte: Wilheim, 1969: 254.

No primeiro esquema morfológico, têm-se a hipótese de um desenvolvimento linear Norte-Sul, paralelo à BR-153, prevista para conurbar-se com a malha urbana de Aparecida de Goiânia antes do ano 2000. (WILHEIM, 1969, p. 254).

No segundo esquema, a hipótese de um desenvolvimento contínuo para Oeste e Sudoeste, abrindo-se em leque e apoiando-se em vias paralelas a Avenida Anhanguera.

No terceiro, o desenvolvimento seria paralelo ao rio Meia Ponte, atravessando a BR-153.

Segundo Wilheim, nas três opções de desenvolvimento linear, apareceria o "caráter germinativo" das vias, porém, somente na hipótese selecionada para implantação foi acrescentado o "caráter específico", no caso de Goiânia, a casa própria.

Conforme Wilheim,

Além dos aspectos normativos, comuns a todo o plano conceitualmente atualizado, prevê-se, como item fundamental de sua implantação, a elaboração de uma "Carta Habitacional de Goiânia". Trata-se de um convênio entre todas as entidades participantes do sistema que constrói conjuntos habitacionais, com a finalidade de adotar critérios de localização desses conjuntos; o objetivo principal é utilizar essas construções como força indutora de desenvolvimento da cidade, neste ou naquele sentido (WILHEIM, 1969). 


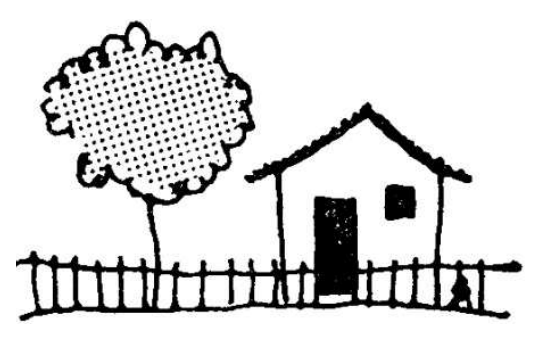

Figura 6 - Ilustração sobre o "caráter específico" do Plano Integrado de Goiânia. Fonte: Wilheim, 1969: 270.

Para chegar às hipóteses morfológicas que estruturam e o orientam a liderança do arquiteto na política urbana do SERFHAU, na maioria das vezes valorizando a questão da habitação, antes é feito o trabalho da equipe multidisciplinar, conforme dito acima, com emprego da metodologia explicativa para conhecimento das estruturas estáticas e da metodologia interpretativa para conhecimento das estruturas dinâmicas ou germinativas.

No plano Integrado feito para Goiânia, o arquiteto expõe a análise explicativa dos aspectos estáticos (estruturas), identificando para isso não propriamente o sistema viário proposto no projeto original da cidade, proposto por Attílio Correia Lima, mas explicando porque a conjunção de estruturas naturais e culturais algumas anteriores, outras posteriores ao plano de Attílio - induzia à falta de organicidade da estrutura viária existente, a fim de compreender de que modo o "caráter germinativo" existente poderia compor a configuração de seu esquema morfológico.

Como observado inicialmente, as características pouco urbanas das vias não pavimentadas de Goiânia, nos anos de 1960, limitavam em muito o numero de estruturas dominantes, o que significava também a falta de organicidade da trama viária e de ligações entre bairros (idem: 253). Wilheim explica que, é possível que essa falta de organicidade também tenha sido decorrência da existência do rio MeiaPonte como um fator de barreira, uma estrutura inicial do sitio natural, mas também de algumas estruturas culturais: a Avenida anhanguera; a estrada de ferro; a rodovia BR-153, já que esse arranjo entre si não estava ligado ao plano de Attílio.

A estrada de ferro limitou a expansão da cidade para o Norte, e o grande vazio do pátio de manobras mais alguns aglomerados desorganizados (Fama, Criméia, Nova Vila e Norte-ferroviário), configuram esta falta de organicidade agravada ainda mais com o movimento decrescente após o surgimento da rodovia BR-153. Então, nesse cenário à norte da cidade, prevalecia como estrutura dominante a própria ferrovia, e não as vias como estruturas germinativas, como diz Wilheim. Por isso, Wilheim observou nesta parte da cidade: aglomerados desorganizados, vazios urbanos, falta 
de organicidade da trama viária e de ligações entre bairros, resultantes de estruturas naturais e culturais dispersivas, como observou nas outras partes da cidade o que gerava a dispersão urbana.

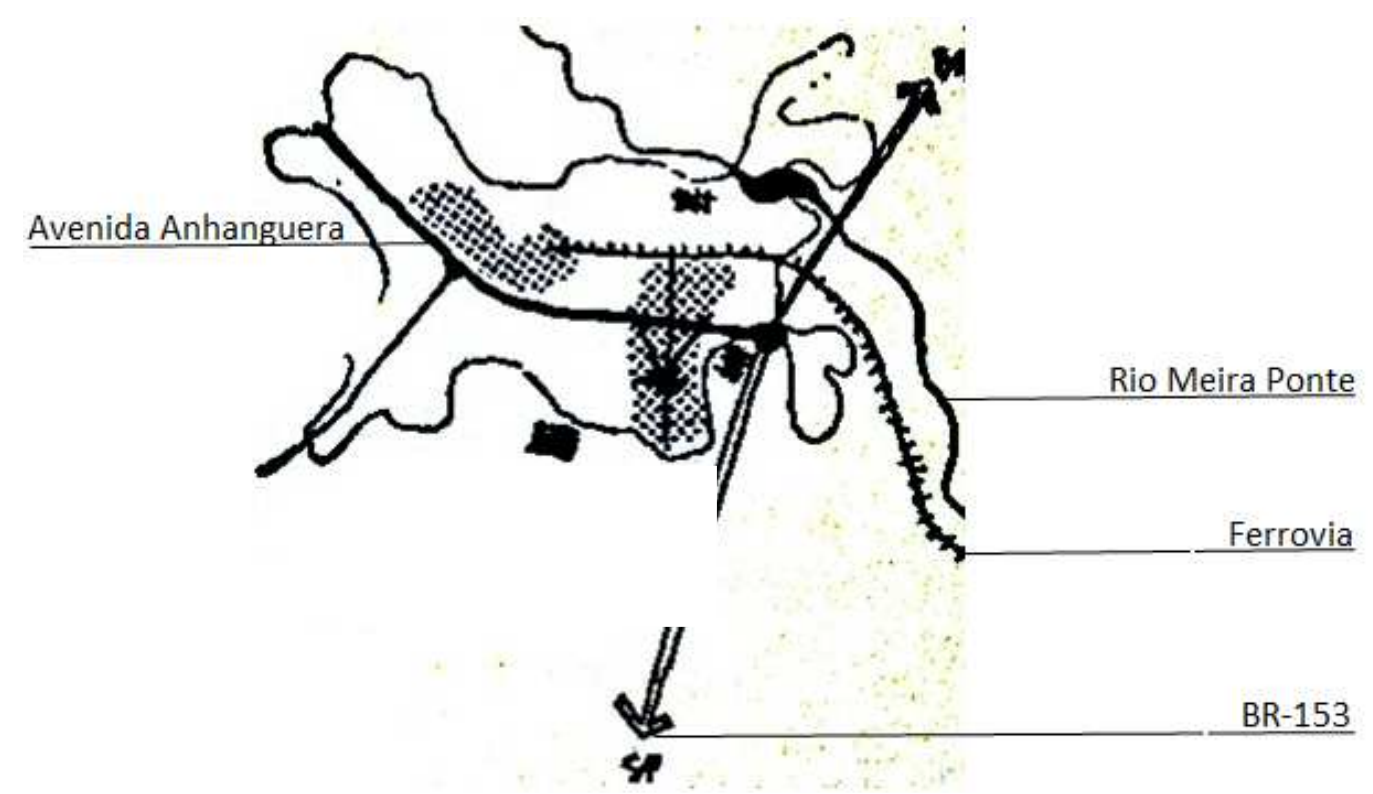

Figura 7 - ilustração sobre a conjunção de estruturas naturais e culturais, na análise explicativa dos aspectos estáticos.

Fonte: Wilheim, 1969: 257.

\section{As estruturas naturais e culturais dispersivas}

Wilheim observa que se essas estruturas continuassem sendo os vetores determinantes de desenvolvimento, ou seja, se a síntese morfológica de sua proposta para Goiânia não fosse colocada em prática, a tendência seria consequentemente:

1) a gradativa e dispersa ocupação do lado Leste da BR-153; 2) o adensamento da faixa de baixa ou nula ocupação solo urbano, entre o setor Sul e Oeste do Centro e a linha que liga a Vila Redenção e União; 3) essa tendência de adensamento ao Sul deixaria disponíveis as áreas a Norte, as quais tanto poderiam vir a ser ocupadas por migrantes, quanto agravadas as características atuais de desordenação e desvalorização; 4) a estrutura Leste-Oeste, ou seja, a Avenida Anhanguera ter que suportar um excesso de atividades, até por ser uma das poucas vias pavimentadas, é confirmada neste sentido como único eixo utilizável; 5) os grandes conjuntos habitacionais que vinham sendo implantados desde 1966 (Bairro Feliz, Vila Iara, Vila União e Vila Redenção), tais como os loteamentos dispersos, aprofundam a dispersão urbana, porém com um efeito mais rápido em virtude da ocupação maciça; 6) a GO-3 e GO-4 são estradas são caminhos de ingresso de migrantes e produtos, responsáveis pelo crescimento de Goiânia; 7) a confusão 
espacial da coexistência de casas e edifícios em torno do Centro, resultante da pouca clareza sobre a função dos setores residenciais valorizados.

Isentas de planejamento, disciplina ou estímulos, essas estruturas que até os anos de 1960 haviam gerado aglomerados desorganizados, vazios urbanos, falta deorganicidade da trama viária e de ligações entre bairros, continuariam produzindo um "entumescimento disforme da cidade" (WILHEIM, 1969, p. 265).

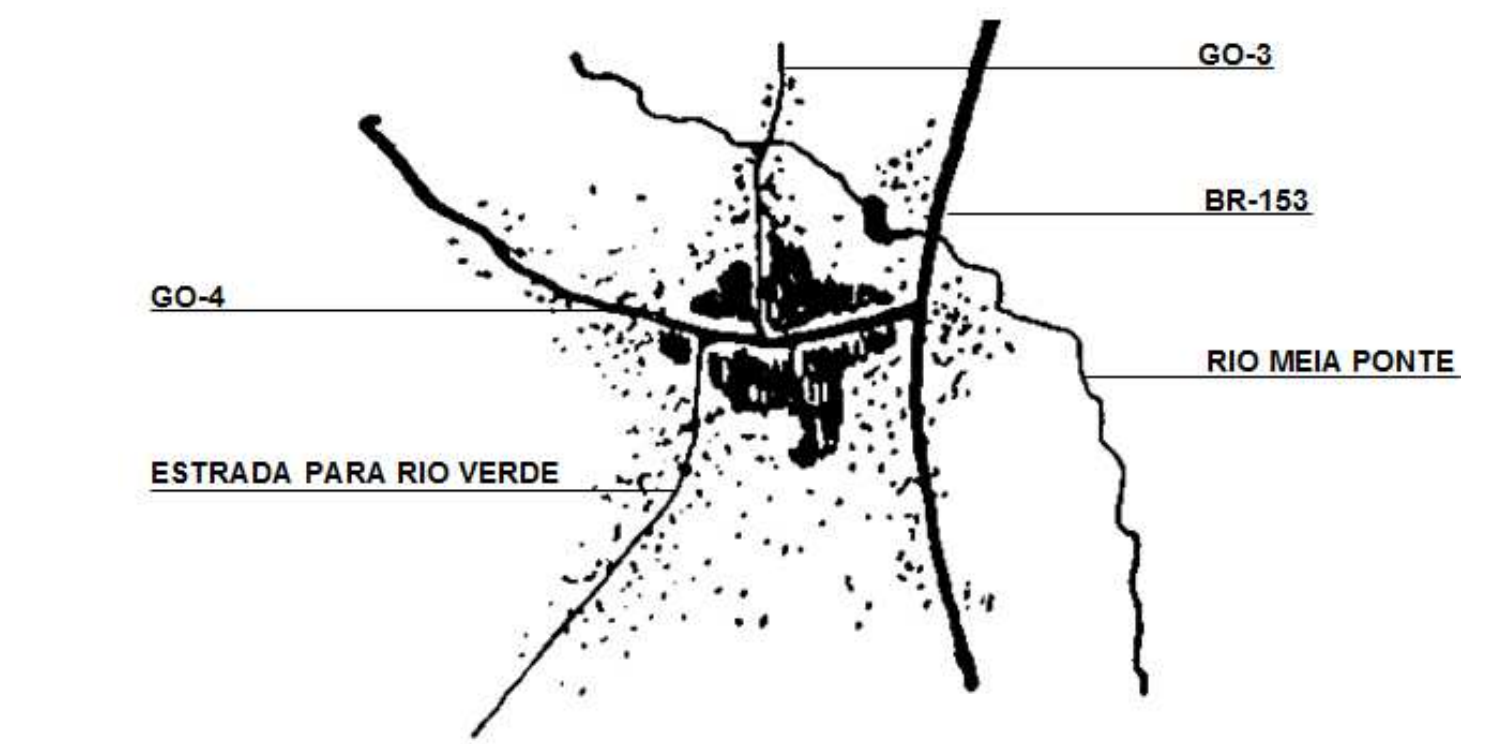

Figura 8 - ilustração de um "entumescimento disforme", no caso de expansão sem planejamento integrado.

Fonte: Wilheim, 1969: 264.

Foi imaginada uma população superior a 1.200.000 habitantes, dispersa em $360^{\circ}$, ocupando um cenário hipotético em que: o vale do Meia-Pontefreiaria de certo modo o desenvolvimento para o Norte, sendo contudo extravasado em alguns pontos; o altiplano ao Sul seria ocupado com baixa densidade, porém conurbando-se com o município vizinho de Aparecida; a Leste da BR-153 haveria também extravasamento de ocupações, e a Oeste, entre o funil formado pelas GO-3 e GO-4 também haveria grande ocupação, crescente em direção a Trindade e Inhumas; a Sudoeste, a estrada que leva a Rio Verde também seria forte vetor de ocupação.

Para evitar essa dispersão em $360^{\circ}$ é que foram propostas três hipóteses de desenvolvimento linear, estruturadas a partir de três vetores germinativos distintos, das quais a escolhida para ser implantada foi a segunda hipótese, onde aparecia também os conjuntos habitacionais como vetor de desenvolvimento.

\section{Hipóteses de desenvolvimento formuladas pelo PDIG até o ano 2000}

Então, empregando o uso de sua metodologia urbanística e a aplicação desta para o caso de Goiânia, define o "caráter específico" que deveria ter o plano URBANA, V.6, no 8, jun.2014 - Dossiê: Cidade e Habitação na América Latina - CIEC/UNICAMP 
Integrado, unindo o "caráter germinativo" da força indutora das vias pavimentadas e o "caráter específico" da situação habitacional, planejando o desenvolvimento da cidade até o ano 2000, quando a população estimada seria de 4.000.000 habitantes.

Nas três sínteses morfológicas Wilheim propõe a síntese visual dos "aspectos germinativos do desenvolvimento", os quais estimulariam processos de transformação, configurando uma espécie de "programação cibernética" que superaria o vício mecânico de séculos de determinismo científico (WILHEIM, 1969: 92; 96). Pressupondo superar o planejamento "em árvore", tão criticados por Christopher Alexander (idem: 96), Wilheim afirma ter criado para o PDIG/Goiânia, não um conjunto de elementos físicos, homogêneos e de relação estática, mas um "sistema", ou seja, um conjunto de elementos.

Vejamos como seria esse sistema. Na primeira hipótese (ver Figura 9), a de desenvolvimento linear Norte-Sul, a BR-153 passaria a ser um vetor predominantemente estabelecido como barreira, ao longo da BR seriam distribuídas indústrias médias, e seriam construídas uma série de vias paralelas para o lado Oeste, inclusive continuando algumas já existentes.

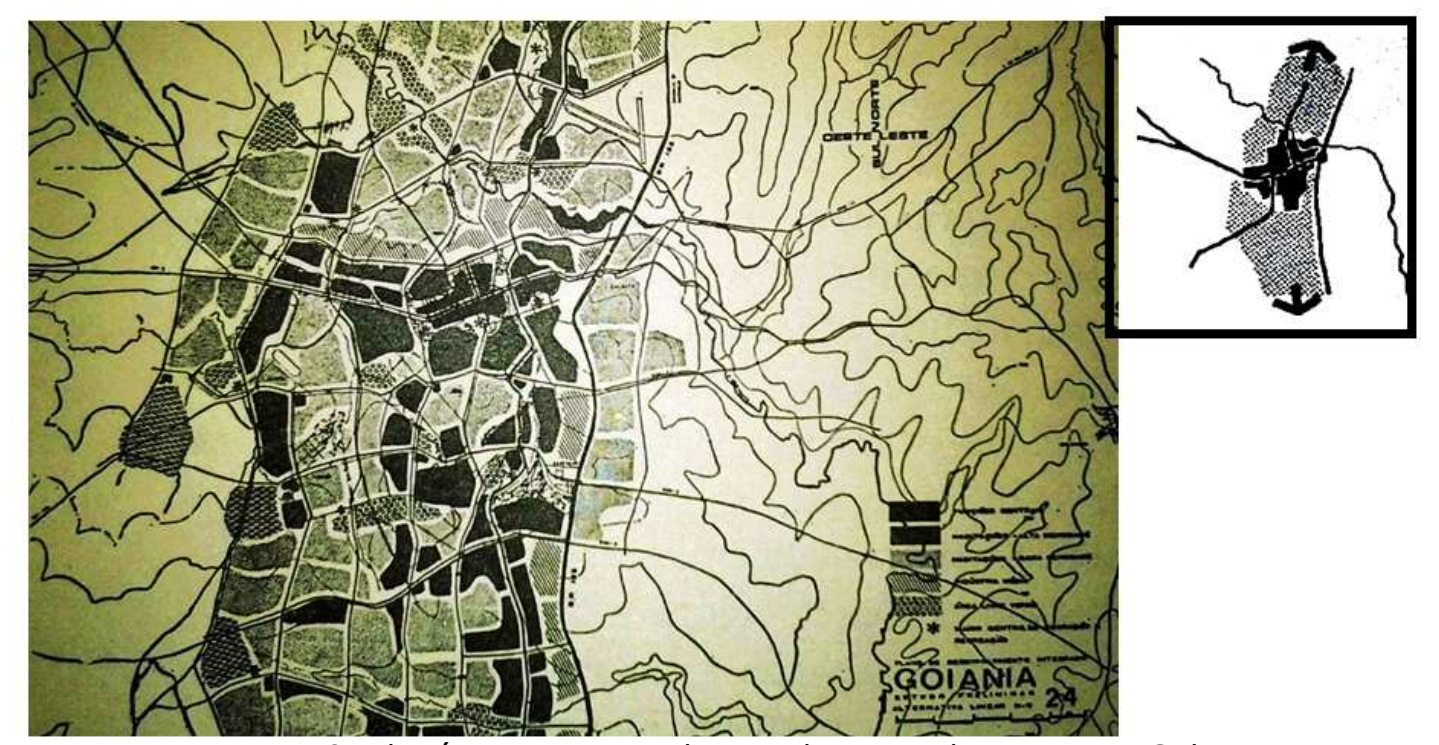

Figura 9 - hipótese 1 para o desenvolvimento linear Norte-Sul.

Fonte: Wilheim, 1969: 266.

O Eixo da Avenida Anhanguera seria totalmente ocupado, e seria reforçado o comércio central. Os equipamentos urbanos (Comércio, ensino e recreação) seriam distribuídos ao longo das avenidas paralelas Norte-Sul, e, nas avenidas paralelas à Anhanguera, auxiliares, seriam distribuídas pequenas industrias. Nessa primeira hipótese, no ano 2000 Goiânia já estaria conurbada a Aparecida, ao Sul. Ao Norte, a 
cidade se desenvolveria percorrendo o vale do Córrego João Leite, e englobaria o aeroporto.

Na segunda hipótese (ver Figura 10), a BR-153 continua como barreira, sendo que o desenvolvimento se daria em seu sentido transversal.

A função comercial da Avenida Anhanguera também seria reforçado, porém a função comercial do Centro seria diminuída com melhor distribuição no sentido LesteOeste, aliando-se atividades terciárias e equipamentos urbanos. As indústrias leves, ao longo de vias paralelas à estrada de ferro, seriam localizadas ao Norte. Como o Setor Palmito é pré-existente à BR-153, este seria exceção ao seu efeito de barreira.

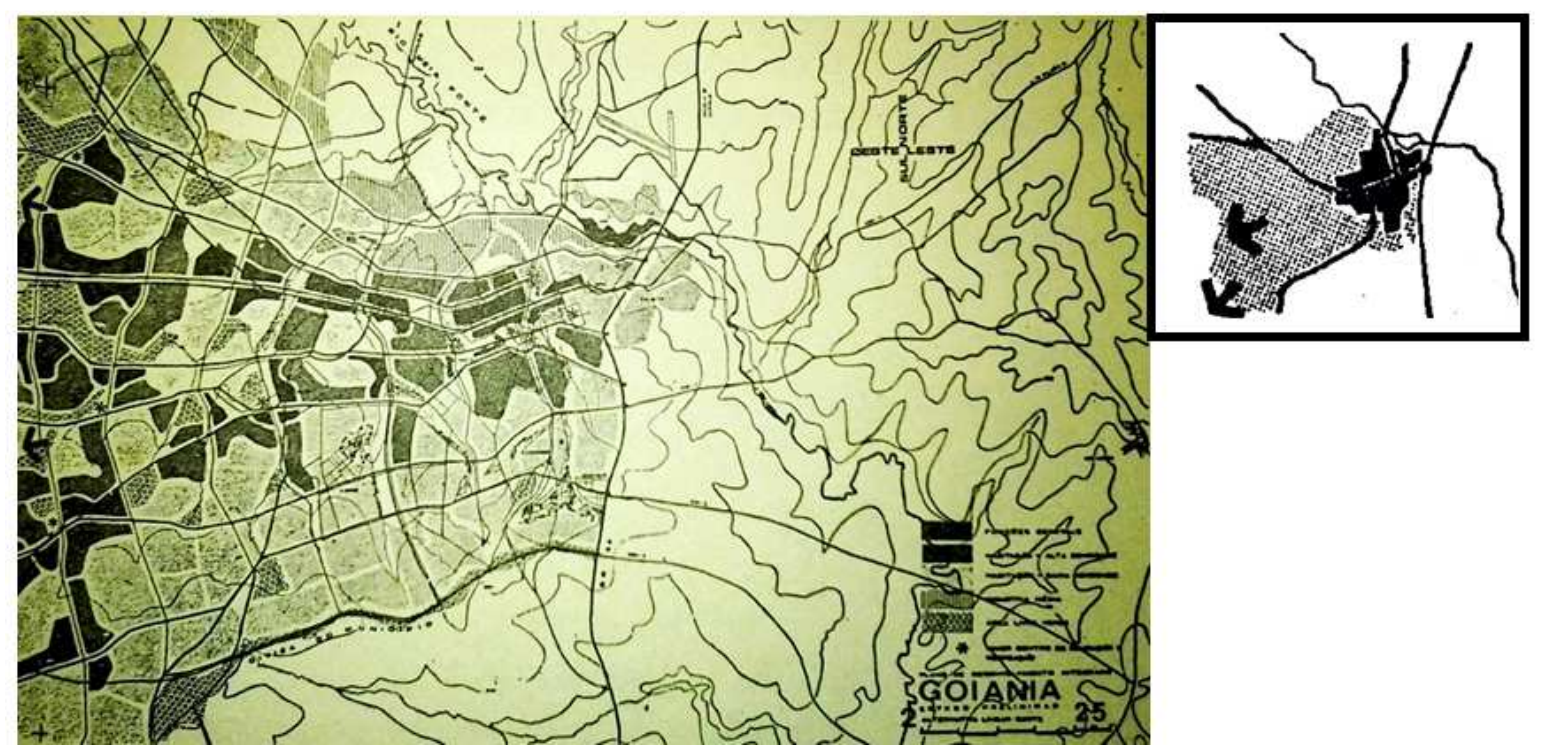

Figura 10 - hipótese 2 para o desenvolvimento linear Leste-Oeste.

Fonte: Wilheim, 1969: 267.

Para garantir uma barreira ao Sul, e evitar a conurbação com Aparecida, seria criada uma reserva florestal a partir do horto florestal existente, e via de contorno a este.

O cone de expansão formado pela G-3 e GO-4 seria uma das formas de garantir a expansão linear, transversal à BR-153.

Na terceira hipótese (ver Figura 11), o desenvolvimento linear se daria ao longo do vale do rio Meia-Ponte, em ambos os lados da BR-153, englobando urbanisticamente a rodovia. Nessa hipótese, o desenvolvimento a Sudeste se daria a partir do Jardim Goiás, cujo vetor de desenvolvimento seria a Rua 83 e o início da nova estrada para Senador Canedo (ver Figura 12). Nesse caso, o eixo principal de comércio deixaria de ser ao longo da Avenida Anhanguera e passaria ao novo eixo ao 
longo de todo o rio Meia-Ponte, com distribuição mais dispersa de pequena e média indústria.
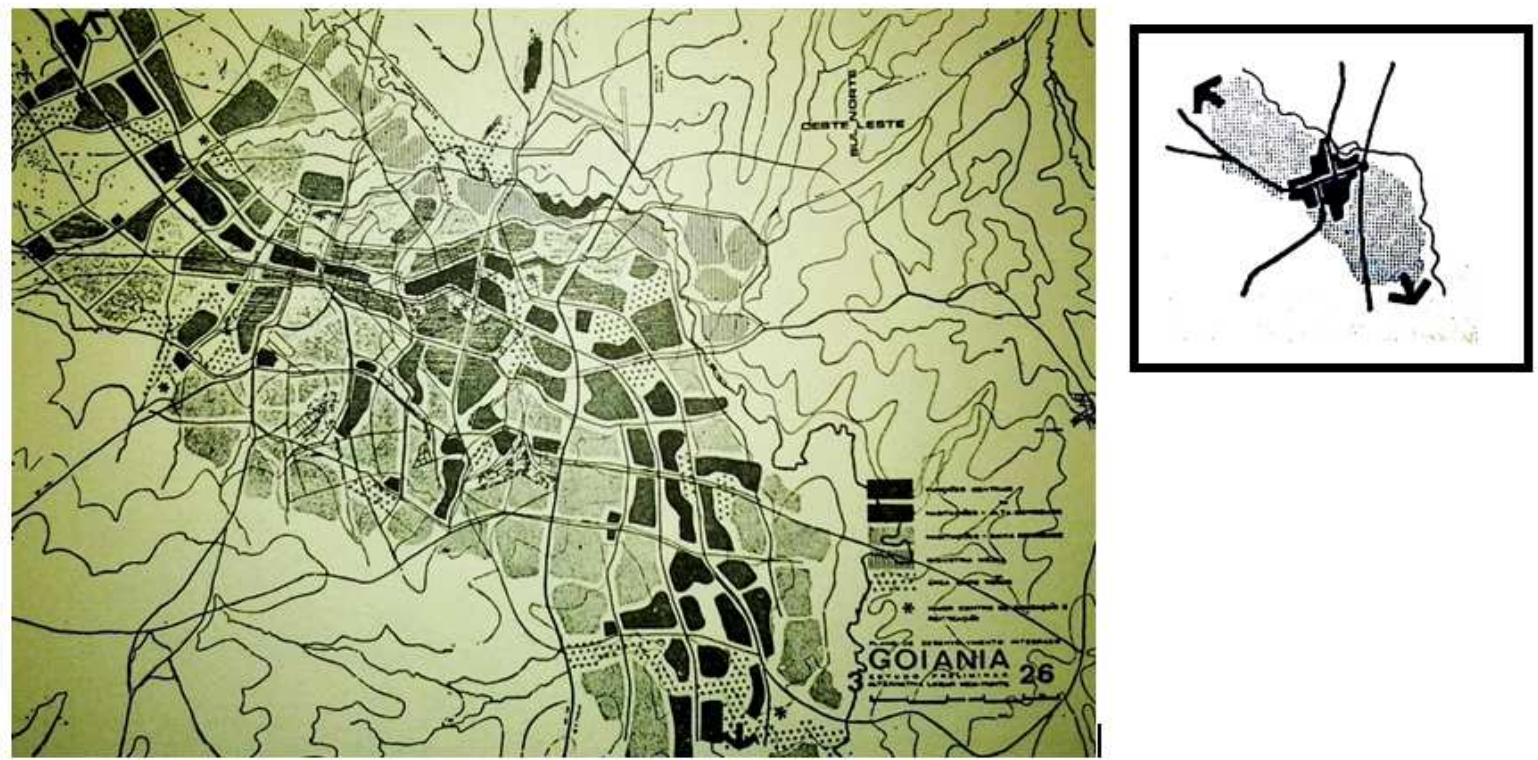

Figura 11 - hipótese 3: desenvolvimento linear ao longo do Meia-Ponte. Fonte: Wilheim, 1969: 268.

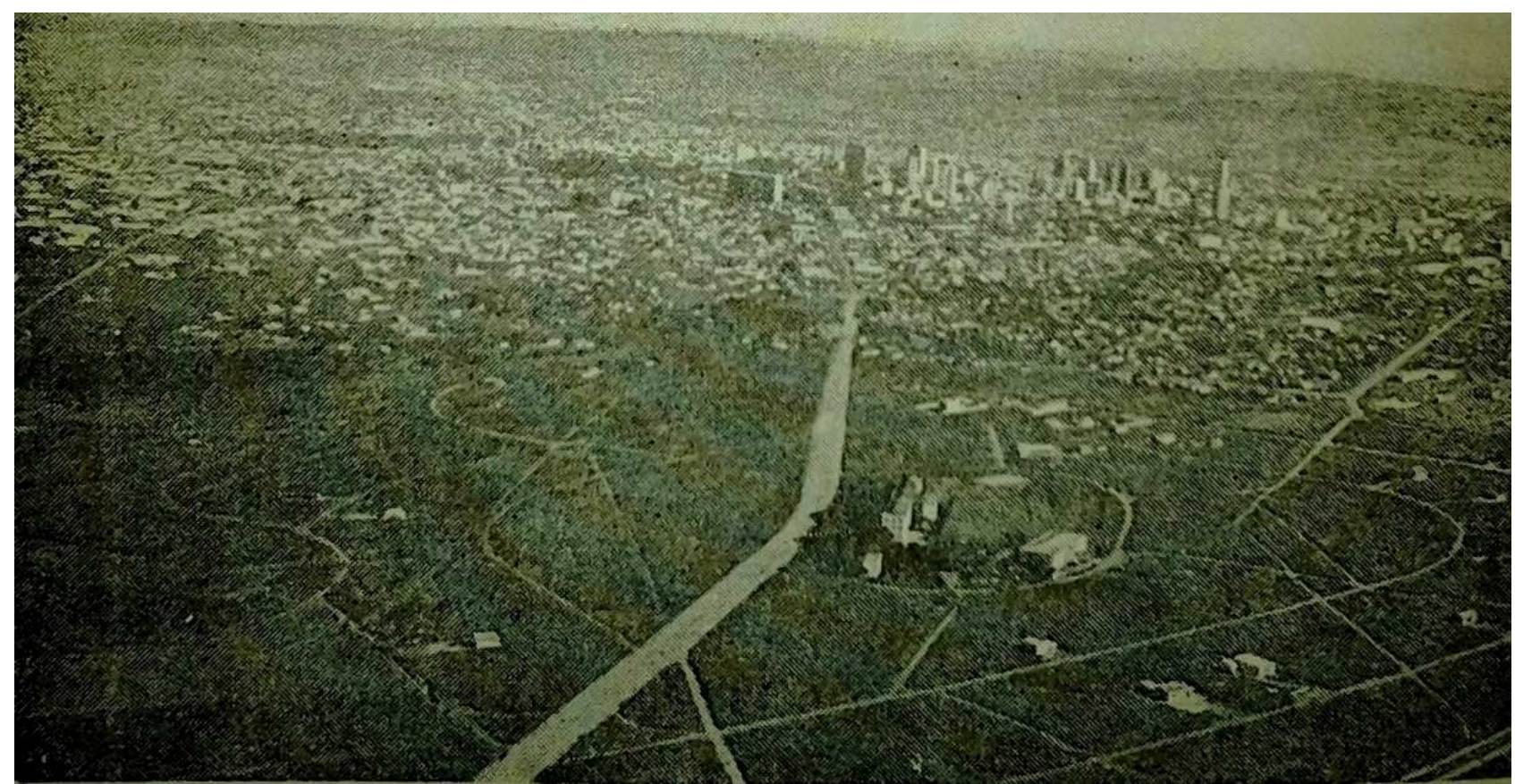

Figura 12 - avenida 83 e estrada para Senador Canedo como vetores de desenvolvimento (no interior do círculo, edifícios da atual sede da SANEAGO, antigo colégio de freiras).

Fonte: Wilheim, 1969: 260.

Essa ligação com o município de Senador Canedo ocorreria, por causa do investimento estatal, que à época visava construir naquele local um polo industrial.

\section{Considerações sobre a hipótese escolhida para ser implantada}


Conforme dito acima, a segunda hipótese foi a escolhida para ser implantada. Embora as três hipóteses tenha sido colocadas para resolver o problema da dispersão urbana por meio da metodologia de implantação de vetores germinativos, é a segunda hipótese que leva em conta o caráter específico da habitação como vetor de desenvolvimento. Percebe-se que nas duas hipóteses descartadas, os vetores de desenvolvimento aliavam, sobretudo a distribuição de pequenas e médias industrias, ou comércio, equipamentos e serviços ao longo das principais vias.

A segunda hipótese agrega todos esses vetores de desenvolvimento, porém baseia-se na implantação de uma política habitacional que já estava sendo feita em Goiânia, desde 1964, iniciada pelo então prefeito Hélio Seixo de Britto junto ao Governo Federal. Por isso Wilheim fez o seguinte comentário:

precisa-se lembrar que os atuais conjuntos habitacionais se localizaram sem critério urbanístico definido; a sua eventual utilização como elemento gerador deriva de uma reinterpretação à qual somos levados pela existência do fato consumado pela peculiaridade de sua localização acidental. (WILHEIM, 1969).

Wilheim insere essa localização "acidental" dos conjuntos habitacionais em Goiânia, na sua análise explicativa sobre a dispersão das estruturas de Goiânia, como vimos anteriormente. Juntamente com esse comentário, Wilheim faz um esquema morfológico da localização desses conjuntos, o que provavelmente originou a referencia para a hipótese de desenvolvimento linear Leste-Oeste (ver Figura 14). Interessante observar que, nessa configuração, aparecem três conjuntos habitacionais posicionados ao longo da BR-153, na análise interpretativa, destacou-se o conjunto habitacional Vila Redenção, porque havia sido inaugurado durante o período em que a equipe de Wilheim fazia os estudos para o PDIG, os outros quatro conjuntos ainda estavam sendo construídos. Na imagem em destaque sobre o conjunto Vila Redenção, aqui reproduzida como Figura 13, consta a seguinte legenda: "no sistema de vida de Goiânia, a habitação (e os conjuntos habitacionais) têm grande potencialidade geradora".

Os conjuntos habitacionais em Goiânia ganharam destaque também porque eram manchas maciças de ocupação, imersas em um território disperso, como dito anteriormente, com grandes vazios a Norte e a Sul, o que destaca ainda mais essas manchas mais evidentes no sentido Leste-Oeste. 


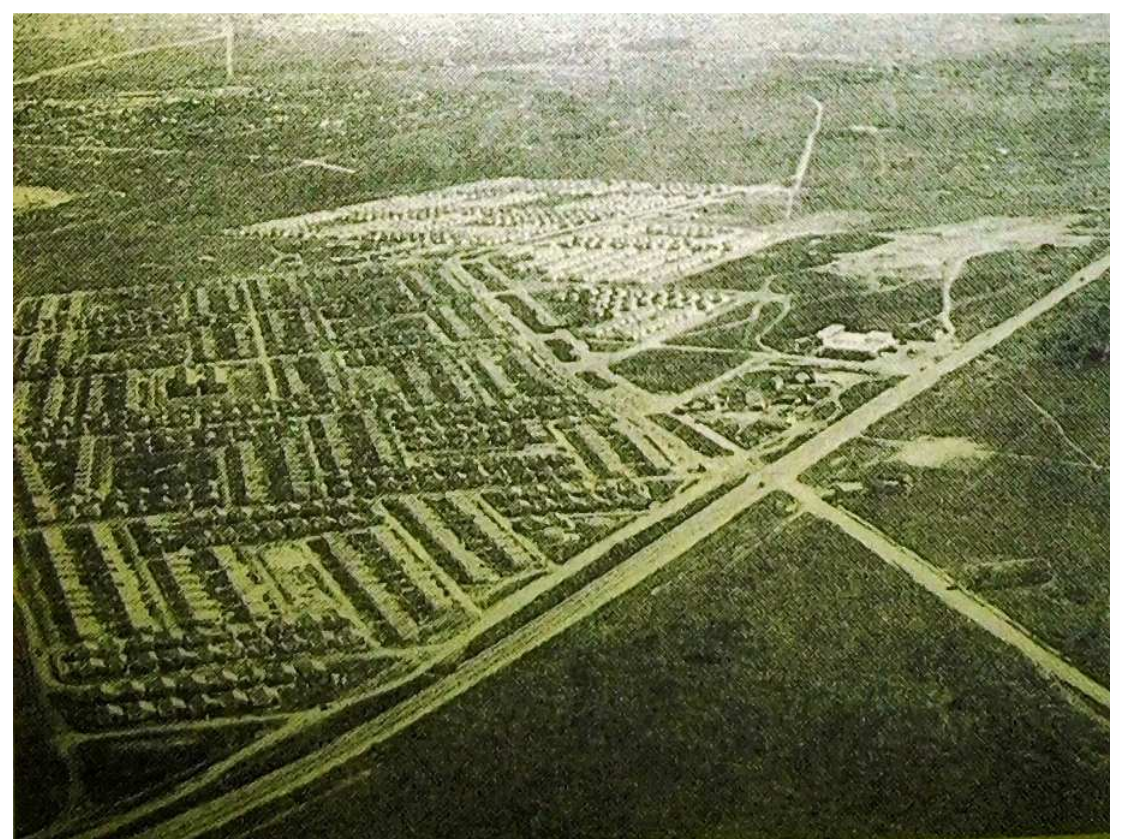

Figura 13 - conjunto habitacional Vila Redenção ao lado da BR-153. Fonte: Wilheim, 1969: 248.

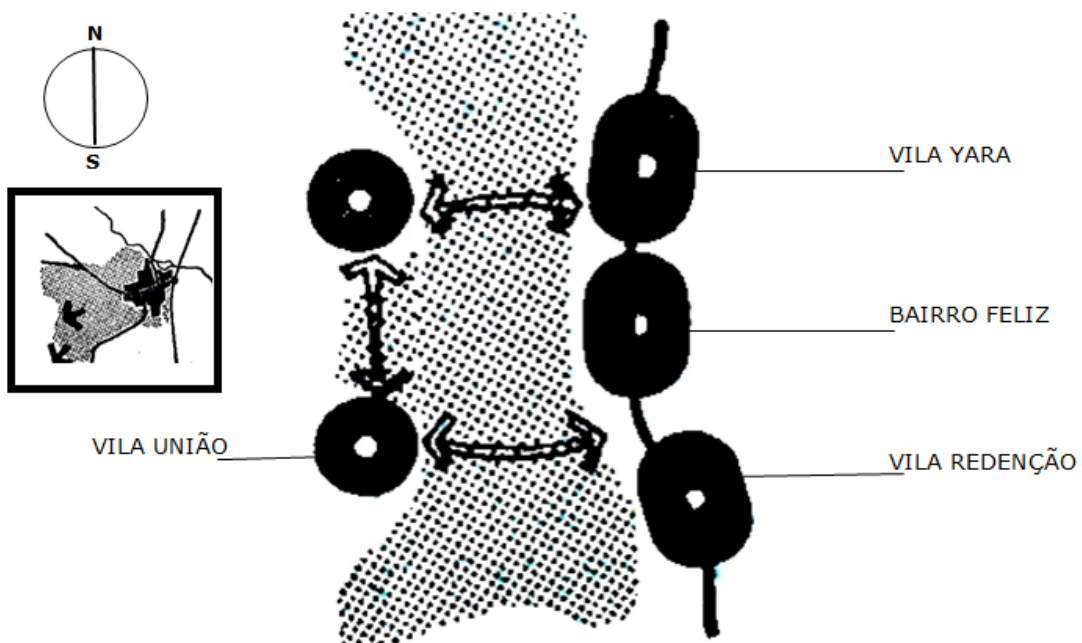

Figura 14 - esquema das disposições dos conjuntos habitacionais em Goiânia, fortemente similar ao esquema morfológico selecionado para implantação do PDIG.

Fonte: Wilheim, 1969: 260.

Como se vê na figura 14, a questão habitacional, a partir dos conjuntos habitacionais já implantados ou em processo de implantação, guarda grandes similaridades com o esquema morfológico selecionado para ser implantado pelo PDIG, ou seja, o desenvolvimento no sentido Leste-Oeste, tendo a BR-153 como limite Oeste.

Para WILHEIM (1969, p. 270) a "busca da casa própria" poderia ser interpretado como esse "elemento subjetivo" integrante do sistema de habitação, cuja 
vitalidade seria capaz de orientar toda a futura ocupação do solo, dirigindo demandas tanto de infraestruturas quanto de transporte urbano.

Sendo o próprio PDIG financiado pelo SERFHAU - Serviço Federal de Habitação e Urbanismo -, a par do belo esforço de teorização desenvolvido por Wilheim, cabe aqui, sem dúvida, a ponderação feita por FELDMAN (2005), de que é recorrente nos Planos Integrados a ênfase em seu caráter centralizador e autoritário, a partir de um raciocínio que estabelece uma relação unívoca entre a instituição e o período político em que é criado e regulamentado.

É evidente o esforço teórico de Wilheim em parecer ser autônomo quanto à urbanística que desenvolve, contudo, é inegável a ingerência política. Interessante perceber que ao expor seus métodos urbanísticos, o autor fala em análises subjetivas e interpretativas, mas não diz abertamente que em tais análises poderia aparecer a muito mais paradoxal participação dos problemas políticos e administrativos. Porém, no PDIG essas questões politicas aparecem de forma tão marcante, que levaram o urbanista a dizer o seguinte:

Planejar em Goiânia significa fundamentalmente utilizar conjuntos habitacionais como força indutora de adensamento e expansão urbana. Mas, além deste aspecto tático importante, o Plano dá ênfase aos problemas políticos e administrativos, muito específicos e ricos em possibilidades. $A$ estratégia do plano não pode dissociar-se de uma estratégia política. E esta é uma importante lição, certamente generalizável do ponto de vista metodológico, - e que obtivemos através da elaboração do plano de Goiânia. (WILHEIM, 1969, p. 247) - grifo meu.

Como se vê, a questão da casa própria e da habitação, no caso do PDIG foi muito mais do que um "caráter específico" do item metodologia urbanística. Ao que parece, a partir do plano de Goiânia, Wilheim passaria a generalizar a questão politica nos procedimentos metodológicos.

Portanto, podemos perceber que, no caso do PDIG o vetor germinativo morfologicamente proposto não deixa de reafirmar a proposta metodológica que vinha sendo empregada em outros planos Integrados, contudo, na questão do "caráter específico" o viés político passou a se impor muito mais fortemente do que a síntese morfológica indicativa do vetor de desenvolvimento.

Por isso que Wilheim associa o desenvolvimento Leste- Oeste a um fator político e administrativo, qual seja, a "Carta de Habitação em Goiânia":

Trata-se de um documento, um convênio em que se estabelecem os critérios gerais de localização e execução dos planos habitacionais, a cargo de todas as 
entidades envolvidas: COHAB, CAIXEGO, BNH, INOCOOP, etc. Essa política geral, à qual se associariam livremente as cooperativas e outros organismos públicos e privados, objetivaria a implantação de conjuntos habitacionais com caráter mais humanos e localizados de molde a se constituir em grande força polarizadora, induzindo o crescimento e adensamento da cidade, na direção indicada pelo Plano Integrado. Uma politica habitacional adequada poderá induzir certas transformações urbanas, contrabalançar os aspectos negativos da especulação imobiliária e constituir-se em força atuante de implantação do Plano. (WILHEIM, 1969).

Como se vê, ao comentar o PDIG, Wilheim incorpora as politicas habitacionais como prática urbanística, a ponto de considera-la indutora de transformações quanto a especulação imobiliária, polarizar, induzir o crescimento e o adensamento.

Na verdade, a inserção explicita da política no PDIG é um fato novo, se compararmos o plano de Goiânia com outros planos anteriormente realizados com a liderança de Wilheim, contudo não é inédita a análise sobre a questão da casa própria como uma questão inerente à especificidade das cidades brasileiras e as do "terceiro mundo".

\section{A questão da casa própria e as cidades subdesenvolvidas}

$\mathrm{Na}$ teoria das cidades que desenvolve para tipificar as cidades do "terceiro mundo" ou subdesenvolvidas, Wilheim vai dizer que, se fosse possível esquematizar a ecologia e uso do solo das cidades brasileiras, deveria começar apontando a existência do constante refluxo de domicílios dos migrantes, que, num primeiro momento chegam ao centro da cidade, para depois refluir para a periferia, onde procurará ambiente semi-rural geralmente acompanhado de "casa própria" (1969, p. 49).

Wilheim faz essas observações sobre a questão habitacional, além de inúmeras outras, na tentativa de adequar metodologicamente a urbanística em pais subdesenvolvido, investigando se realmente existe a "cidade subdesenvolvida" para propor inovações no método urbanístico, porque "mesmo os aspectos 'modernos' que venha a apresentar são alterados em seu significado, em virtude de seu enquadramento numa economia subdesenvolvida" (p. 240).

Nesse contexto, a cidade adquire grande vitalidade e elevada taxa de crescimento antes e independentemente de qualquer industrialização de porte. 0 ineditismo da urbanização latino-americana se dá, entre outros aspectos, com limitadas possibilidades de industrialização, sendo esta urbanização fator e condição de industrialização, representando economias externas à empresas, à medida que as cidades oferecem às industrias facilidades de mútua complementação. 
O desenvolvimento sem urbanização é um fenômeno indesejável, mas não há nada pior do que a urbanização sem desenvolvimento, porque as carências de equipamento urbano se acrescenta a demanda em empregos. (UNESCO apud WILHEIM, 1969).

Esse seria um círculo vicioso que fazia da urbanização ligada a fatores exógenos, para os quais interessavam o fenômeno da "explosão" da "superurbanização", haja vista que a economia moderna exige concentração em cidades, correspondente a uma inercia histórica que é objetivada pela quantidade de investimentos, repetidamente colocados nas cidades: "é pouco provável que se venha a abandonar estes investimentos, passando-se a viver em formas de 'urbanizações' regionais, diminuindo a importância polarizadora da cidade" (idem, p. 419).

Ao contrário, possuir a terra (e, consequentemente, a casa, o abrigo, construído geralmente com as próprias mãos, com a ajuda de vizinhos) é, nas cidades, um desejo mais consciente que no campo, sendo, por isso, a compra da terra um símbolo de garantia face à insegurança do desemprego. É por isso que, apesar da penúria e baixo nível econômico, as periferias pobres das grandes cidades apresentam o maior índice de "casa própria" (idem, p. 46)

Com isso, nas cidades "subdesenvolvidas" a expansão produz uma ocupação tentacular (idem, p. 48), caótica e descontinua ao solo adjacente à cidade. A trama já descontinua pelo crescimento conurbativo, permanece descontinuo ou fracamente ligado á trama pré-existente. Na criação desse cenário, está o arranha-céu, que simboliza a riqueza, o avanço, o progresso de uma cidade, imagem reforçada pelos investimentos oficiais e particulares epidérmicos, oriundos da especulação e do mecanismo dos loteadores a exigirem obras publicas, geralmente sem planificação (idem, p.31-32).

Porém, da pobreza em equipamentos e estruturas decorre a grande força de indução da "oferta de lotes", sendo suficiente que uma ligação viária pavimentada, para que esta se torne forte fator de interesse de venda induzindo o crescimento da cidade naquela direção. Nota-se assim, que a ligação viária como requisito mínimo exigido do "loteador" cresce em importância diante da carência de redes e equipamentos. Da gleba, comprada ou herdada, o "loteador" separa parcela, projeta sua divisão e a oferece à venda em condições de pagamentos parcelados; à medida em que casas e pessoas se estabelecem, surge um esquema de pressão desses habitantes sobre a Prefeitura, exigindo "melhorias urbanas" (calçamento, esgoto pluvial e sanitário, água, luz, escola, transporte coletivo, telefone etc). "A tacha de 
lucro e o baixo investimento necessário para este comercio, transformaram a maioria das cidades brasileiras numa colcha de retalhos" (WILHEIM, 1969, p. 47).

Nesta cidade subdesenvolvida, a vida de periferia parece ser menos diferente do ambiente semi-rural do qual partiu, sendo mais resultante do custo do terreno e da súbita oferta de loteamentos do que da busca saudosa de ambiente rural.

Comparativamente, Wilheim diz que os problemas básicos para a compreensão das cidades subdesenvolvidas podem ser encontrados em cidades desenvolvidas, mas não de modo simultâneo, e em contexto de crescimento médio do país em torno de $6 \%$ ao ano (idem, p. 51). Não se encontra na Europa a complexidade psicológica (idem, p. 47) advinda das peculiares demandas por insegurança e o loteamento sem investimento.

Assim como ao nível metodológico é possível estabelecer algumas generalidades, - as cidades brasileiras permitem-nos identificar alguns aspectos morfológicos que correspondam em sua generalidade, a denominadores comuns, caracterizando a dinâmica típica da cidade subdesenvolvida - no caso em tela, a questão habitacional. Nestes elementos morfológicos básicos estão as forças geradoras (ou germinativas) da expansão urbana (p.106).

\section{Breves considerações finais}

Neste texto, o objetivo foi identificar o momento de inserção da politica e mais especificamente da politica habitacional na metodologia urbanística desenvolvida por Jorge Wilheim no final dos anos de 1960, a partir do PDIG. Esse momento foi identificado, segundo o próprio Wilheim, a partir do PDIG.

Não foi proposto nesse texto estudar as consequências da implantação da hipótese Leste-Oeste, na morfologia citadina após os anos de 1970, o que seria salutar, até para compreendermos qual teria sido a influência dessas politicas propostas para o desenvolvimento urbano em 360 graus, e não de forma linear, como esperava Wilheim.

\section{Referencias}

AB'SABER, A.N. Geografia e planejamento. São Paulo: Ed. Universidade de São Paulo (Série Geografia e Planejamento). 1969.

AZEVEDO, Eurico de Andrade. Avaliação do Planejamento Municipal no Estado de São Paulo. Relatório de pesquisa, FAPESP, USP/EESC. 1976.

BASTOS, Maria Alice J. e ZEIN, Ruth V. Brasil: arquiteturas após 1950. São Paulo: perspectiva, 2010. 
BONDUKI, Nabil. Origens da habitação social no Brasil: arquitetura moderna, lei do inquilinato e difusão da casa própria. São Paulo: Estação Liberdade, 2004. CAMPOS, Paola R. e MENDONÇA, Jupira G. Estrutura socioespacial e produção habitacional na Região Metropolitana. In CARDOSO, Adauto Lucio (Org.). 0 Programa minha casa minha vida e seus efeitos territoriais. Rio de Janeiro: Letra Capital, 2013.

FELDMAN, Sarah. O arranjo SERFHAU:assistência técnica aos municípios/órgãos de planejamento de engenharia consultiva. Anais do XI ENANPUR. Salvador, 23-27 de maio de 2005.

KOPP, Anatole. Quando o moderno não era um estilo e sim uma causa. São Paulo: Nobel/Edusp, 1990.

MARICATO, Ermínia. Brasil, cidades. Petrópolis: Editora Vozes, 2001.

. O impasse da política urbana no Brasil. Petrópolis: Editora

Vozes, 2001.

MORAES, Lucia Maria. A segregação planejada: Goiânia, Brasília e Palmas. Goiânia: Ed. da UCG, 2003.

MOTA, Juliana Costa. Goiânia, anos 60: os planos diretores de Luís Saia e de Jorge Wilheim/Serete e as diferentes práticas de planejamento urbano nos períodos pré e pós SERFHAU. Anais do XI ENANPUR. Salvador, 23-27 de maio de 2005.

REIS FILHO, Nestor Goulart dos. Revista Acrópole n. 319, p. 24-27.

RIBEIRO, Luiz C. Q. \& PECHMAN, Robert M. O que é questão da moradia. São Paulo: Ed. Brasiliense, 1983.

RIBEIRO, Luiz C. Q.\& AZEVEDO, Sérgio de. A produção da moradia nas grandes cidades: dinâmica e impasses. In: RIBEIRO, Luiz C. Q. \& AZEVEDO, Sérgio de. A crise da moradia nas grandes cidades: da questão da habitação à reforma urbana. Rio de Janeiro: Editora UFRJ, 1996.

ROLNIK, Raquel. A cidade e a lei: legislação, política urbana e territórios na cidade de São Paulo. São Paulo: Studio Nobel - FAPESP, 1997.

SOUZA, AngelaGordilho. Limites do habitar: segregação e exclusão na configuração urbana contemporânea de Salvador e perspectivas no final do século XX. Salvador: EDUFBA, 2008.

TAFURI, Manfredo. Viena Rossa. Milão: Electra, 1986.

WILHEIM, Jorge. Urbanismo no subdesenvolvimento. Rio de Janeiro: Editora Saga, 1969. 
São Paulo: uma interpretação. São Paulo: Editora Senac São Paulo, 2011.

\section{Lista de Siglas:}

SEPLAM - Secretaria Municipal de Planejamento;

SERFHAU - Serviço Federal de Habitação e Urbanismo;

BNH - Banco Nacional de Habitação;

PDIG - Plano de Desenvolvimento Integrado de Goiânia;

SFH - Sistema Financeiro da Habitação;

IAB - Instituto de Arquitetos do Brasil; 